https://doi.org/10.46291/ISPECIJSSHvol5iss1pp32-50 Accepted: 30-01-2021

\title{
The Case of Zelman v Simmons-Harris and the Shifts in American Secularism
}

\author{
Nesrin ÜNLÜ \\ Marmara University, Sociology of Religion, nesrin.unlu@ @marmara.edu.tr \\ ORCID: 0000-0003-4981-1966
}

\begin{abstract}
Through the lenses of the case of Zelman v Simmons-Harris(2002), this article discusses the American concept of secularism. Unlike the direct government aid to religious activities in various European and Turkish political systems, the American government supports religious instruction only indirectly. Even though the government programs providing financial aid for religion has always faced rigorous examination in the Supreme Court, the current case law of the Court opens the door for a significant amount of unspecified cash flow to religious schools. Thanks to this constitutional pass, it is possible for future politics and legislative endeavors to reshape the contours of state-religion relations in the field of education. Thus, the distinct feature of American secularism based on separation between church and state might bend further.
\end{abstract}

Keywords: Zelman v Simmons-Harris, America, Secularism

\section{Introduction}

Aid to parochial schools has been one of the most controversial cases among the establishment clause cases (Greenawalt, 2008 and Griffin,2010) in the US. Indeed, the first establishment case decided whether New Jersey could allocate public funds to parochial school students to be used as bus fares. (Everson v. Board of Education 1947). In the 19th century, the public schools were under the influence of the Protestant churches; other religious groups, especially Catholics, were discriminated against in the public schools. As more Catholic immigrants arrived at America in the mid 19th century, Catholics were able to establish their own schools and hospitals to resist the Protestant influence. They argued that since the government supported public schools dominated by Protestants, the government should also provide the Catholic schools with necessary support. In this context, the Blaine Year 5/ 2021, Volume-5, Issue-1 | WWW.ispecjournal.org 
Amendment was introduced to ban the government aid to parochial schools as well as to eliminate any religious influence from schools. (Fowler et al. 2004). Although the debate on aid to parochial schools developed in this background, one should pay attention to the transition in prevailing religious controversies in the US. The main rivalry in the American public today is not between Protestantism and Catholicism, but between religion and nonreligion.

Davis argues that the recent Supreme Court cases concerning government aid to parochial schools signal a doctrinal focus on 'equal treatment' of religion. While many Americans celebrate these decisions arguing that equal treatment ends discrimination against religion, many Americans are dissatisfied with the recent trend asserting that separation of church and state should be the main guarantor of liberties (Davis, 2005)

\section{Brief Overview of Zelman $v$ Simmons-Harris (2002):}

The State of Ohio initiated the Cleveland Scholarship Program in 1996 providing scholarships for low-income families to be redeemed in secular or religious private schools. Eligible parents received vouchers in the form of a check covering as much as $90 \%$ of the tuition capped at $2,250 \$ .82 \%$ of the participating schools were religiously affiliated schools in the 1999-2000 academic year and $96 \%$ of the scholarship students were enrolled in parochial schools. (Zelman v Simmons-Harris, p.639). The program received strong endorsement from participating low-income families. (Peterson et al, 1999, p. 14 and Crisafulli, 2003, p. 2227-8) However, the program also faced legal challenges both on state and federal levels. In 1999, the Ohio Supreme Court did not find any violations of the Establishment Clause of the State in the voucher program; however, ruled that the program had some procedural violations (Peterson et al, 1999, p.1). Some Ohio citizens protested against the voucher program and brought the issue to the federal court arguing that the Establishment Clause of the Constitution prohibited such aids to religious schools (Crocker, 2005, p. 398). The US District Court of Northern District of Ohio found that the voucher program was not neutral. The Court stated that "because of the overwhelmingly large number of religious versus nonreligious schools participating in the Voucher Program, beneficiaries cannot make a genuine, independent choice of what school to attend. A program that is so skewed toward religion necessarily results in indoctrination attributable to the government and provides financial incentives to attend religious schools. For both of these reasons, the court finds the Program to

Year 5/ 2021, Volume-5, Issue-1 | WWW.ispecjournal.org 
be in violation of the Establishment Clause" (72 F.Supp.2d 834 (1999)). The Sixth Circuit Court confirmed the ruling of the district court and then, the case was appealed to the Supreme Court.

\section{Opinion of the Court:}

In 2002, the Supreme Court evaluated the constitutionality of the Cleveland school voucher program and ruled that the constitutional principle of separation between church and state was not violated, and hence reversed the Sixth Circuit's decision ${ }^{1}$ that identified the voucher programs as unconstitutional aid to religious schools. By this decision, the Supreme Court opened the door for substantial public funding that indirectly can reach to religious institutions (Crocker, 2005, p. 395-6).

The main task of the Court was to determine whether the government had the aim to promote or inhibit religion. (p.644-9). According to the Court, the voucher program had a "valid secular purpose" (p.649). Furthermore, the program was neutral towards religion as the aid was provided "directly to a broad class of individuals defined without reference to religion" (p. 653). As the individuals in the program had a choice to enroll in religious or secular schools, the government did not aim to promote or inhibit religion according to the Court.

The Opinion highlights the worrisome background against which Ohio created the voucher program in question. There were 75.000 students in the Cleveland Schools District. Students from low-income and minority families constituted the majority of these students. In 1995, Ohio faced an educational emergency. These public schools became the worst performing schools across the nation to the point that a few of Cleveland's high school graduates could read and write properly (p.644).

The Opinion also emphasizes that the families eligible to receive scholarships have the four options to choose from: 1) Community schools 2) magnet schools 3) participating private schools 4) participating inner-city public schools (p.651). As opposed to the district and the circuit courts, the Opinion said that the parents had "true private choice" (p.640). Moreover, even though \% 96 of the students participating the voucher program were enrolled in religious schools, Justice O'Connor's concurring opinion argues that when all parents' all choices are calculated, the religious schools represented only \% 16.5 of Ohio's overall educational spending (p.664). In short, the majority opinion does not consider the number of students

\footnotetext{
${ }^{1}$ See Sixth Circuit, Simmons-Harris v Zelman, No: 00-3055/3060/3063.

Year 5/ 2021, Volume-5, Issue-1 | WWW.ispecjournal.org
} 
redeeming vouchers at religious schools relevant to the establishment question because this statistic occurred as a result of private choice of participants instead of 'financial incentives that skewed it toward religious schools" (p.640).

Justice O'Connor's concurring opinion states that this decision upholding the voucher program is not a "dramatic break from the past" (p.663). She argues that local governments already provide religious institutions with tax exemptions, which translates into a much larger sum of money compared to 8.2 million $\$$ in the voucher case. Furthermore, O'Connor continues, religious institutions benefit Religious institutions also benefit from many government programs, including Medicare, Medicaid, Pell Grants, and the Child Care and Development Block Grant Program. In short, the voucher program is "neither substantial nor atypical"' according to O'Connor (p.668).

\section{Dissenting Opinions:}

Justice Breyer, and Souter wrote dissenting opinions. Justices Breyer, Ginsberg and Stevens joined Souter's opinion (p.686). Souter's dissenting opinion argues that the majority rejected prior case law by upholding the voucher scheme. The Court had thoroughly examined whether the aid can be diverted to the religious instruction in the previous cases. Vouchers simply cover school tuitions that also include religious education. Previously, the Court had not allowed such a divertible government aid to religious institutions. Second, prior to this decision, the Court had not allowed allow any substantial government aid for religious institutions.

Souter's critique continues over the concepts of 'neutrality' and 'true private choice', which constituted the rationale of the majority opinion. According to the dissenting judges, the parents did not have a genuine independent choice given the fact that 46 of the 56 participating schools were sectarian schools. Furthermore, non-sectarian schools were more expensive, therefore, the vouchers could cover less percentage of such schools as opposed to the participating sectarian schools. Thus, the genuine choice that the parents in Cleveland had was between failing public schools and sectarian schools. Indeed, only one out of three families agreed the religious teaching of the school that their children enrolled. (p. 704)

In short, according to Souter, the majority's decision created a new era "in which the substantial character of government aid is held to have no constitutional significance, and the 
espoused criteria of neutrality in offering aid, and private choice in directing it, are shown to be nothing but examples of verbal formalism."( p. 688)

Justice Breyer also wrote a separate dissenting opinion to emphasize the risk of religious based social conflict and divisiveness in the society. According to Breyer, aid to parochial schools are different from other forms of government aid to religious institutions because such schools teach 'religious truths' to impressionable young children. (p. 726)

\section{An Accommodationist Shift from Everson to Zelman: Brief Overview of the Establishment Jurisprudence of the Supreme Court on Parochiaid cases:}

The Establishment Clause of the First Amendment states that "congress shall make no law respecting an establishment of religion." Although parties have usually agreed that the Clause prohibits establishment of any official religion, the implementation of the clause have been raised different opinions in the American legal history. Even though the Supreme Court developed tests to standardize the establishment jurisprudence, many critics highlight the lack of consistency (Bell, 2001, p. 1274). In Lemon v Kurtzman (1971), the Court also acknowledges the difficulty of the evaluation by saying that "we can only dimly perceive the lines of demarcation in this extraordinarily sensitive area of constitutional law"(Lemon $v$ Kurtzman, p. 612). Similarly, in his dissenting opinion in the case of Wallace $v$ Jaffree, Justice Rehnquist states that the Establishment Jurisprudence "has produced only consistent unpredictability" (Wallace v. Jaffree (1985), p. 112).

According to Greenewalt, there are competing visions about the constitutional principle of disestablishment. Some read the framers' disestablishment as a separation between church and state while others understand it as a non-preferential treatment of religion by the federal government to protect religious liberties. On the other hand, some argue that the contemporary establishment jurisprudence displays a developing history with an origin in securing interests of predominantly Protestant states on the one hand and a proper evolution towards a secular separationist model on the other hand similar to the evolution in the Courts' jurisprudence on Civil Rights (Greenewalt, 2005, p. 369-70)

According to Philip Hamburger, disestablishment in the founding era did not mean complete separation of church and state. Rather, the concept was understood in relation to Catholicism and theocracy, that is to say, it reflected anti-Catholicism and anti-clericalism; yet it did not eliminate state-sponsored religion from state institutions such as schools. Thus, the federal

Year 5/ 2021, Volume-5, Issue-1 | WWW.ispecjournal.org 
government was required not to establish any religion, but de facto state Protestantism was visible in public life and schools (Hamburger, 2012, p.11) Similarly, Daniel L. Dreisbach argues that Thomas Jefferson's oft-quoted metaphor 'the wall of separation between church and state' was intended for the federal government's limits. Yet, today the metaphor is used to justify separationist secularism (Dreisbach, 2002, p. 54). On the other hand, Munoz argues that it is extremely difficult to discern the framers' intentions. That is why, both the "strictseparationists" and the "non-preferentialists" use Madison's views on the separation of church and state to support their claims (Munoz, 2013, p. 17-8).

In addition to the discussions on the framers' intentions, there are also different schools of constitutional interpretation; Originalism, Textualism, Common Law Constitutionalism and Living Constitutionalism being the main ones (Marietta, 2014, p.92). Of course, this variety of opinions on the constitution also appear among the interpretations of the Supreme Court justices. Yet, everybody accepts the non-establishment principle and develop their arguments within the principle whether convincing or not. Among the establishment clause cases, the most Controversial ones have been the cases involving state aid to parochial schools, the cases involving religious displays in public property, and the cases involving religion in public schools (Greenewalt, 2008, Griffin, 2010). Since cases involving state aid to parochial schools is the subject of this article, I will review history of these cases below.

The first Establishment Clause case in the Supreme Court's history was a parochiaid case. In this case, Everson v Board of Education (1947), the Court decided whether New Jersey could allocate public funds to parochial school students to be used as bus fares. The ruling upheld the New Jerseys policy while emphasizing government neutrality towards religion. This case was a first attempt to define the parameters of the Establishment Clause (Bell, 2001, p. 12845). ${ }^{2}$ The opinion stated that "Neither a state nor the Federal Government can, openly or secretly, participate in the affairs of any religious organizations or groups, and vice versa. In the words of Jefferson, the clause against establishment of religion by law was intended to erect "a wall of separation between church and State" (Everson v Board of Education, p. 16). In short, even though the Court upheld the New Jersey policy, it made a very robust antiestablishment statement in the Everson case.

The following parochiaid case was Board of Education $v$ Allen(1968) in which the Court decided whether lending textbooks to parochial school students violated the Establishment

\footnotetext{
${ }^{2}$ Also see Justice Souter's dissenting opinion at Zelman $v$ Simmons-Harris Year 5/ 2021, Volume-5, Issue-1 | www.ispecjournal.org
} 
principle of the Constitution. The parochial school students could barrow only the textbooks approved by public school authorities (Board of Education v Allen, p. 241). The Court ruled that the text-book lending program had 'a secular legislative purpose' and its 'primary effect' neither promote nor inhibited religion. So, the program was able to pass the tests and as a result was upheld as constitutional (Board of Education v Allen, p. 244-5).

The next parochiaid case was Lemon v Kurtzman (1971) in which the Court decided whether Rhode Island and Pennsylvania could pay salaries of parochial school teachers employed to teach secular subjects. The Court ruled that both statutes were unconstitutional. (Lemon $v$ Kurtzman, p. 607). In Lemon, the Court applied a three-pronged test which has become known as the 'Lemon test'. Justice Burger wrote in the opinion that 'Every analysis in this area must begin with consideration of the cumulative criteria developed by the Court over many years. Three such tests may be gleaned from our cases. First, the statute must have a secular legislative purpose; second, its principal or primary effect must be one that neither advances nor inhibits religion" (Lemon v Kurtzman, p. 612). The lemon test has been the core principle guiding the decision-making on the Establishment Clause even though it has been criticized by some justices such as Burger and Rehnquist in Wallace v. Jaffree (1985), O'Connor and Scalia in Kiryas Joel v. Grumet (1985), Scalia in Lamb's Chapel v. Center Moriches School District (1993), Kennedy in Allegheny v. ACLU (1989) as well as by some scholars for being hostile to religion (Kritzer and Richards, 2003, p. 830).

The following case of Committee for Public Education \& Religious Liberty v. Nyquist (1973) was decided with the same rationale as the Lemon. The Court ruled that tuition reimbursement, maintenance and repair grants, and tax credit programs provided to parochial schools and parents of parochial school children unconstitutional because they had the impact of advancing religion (Crocker, 2005, p. 410).

In Meek $v$ Pittenger (1975), ${ }^{3}$ the Court evaluated the constitutionality of Pennsylvania's statute that offered educational programs including lending instructional materials and equipment to non-public schools and providing auxiliary services via public schoolteachers. The Court ruled that only lending textbooks, analogues to the 1968 Allen case, was permissible because the program was available to all school children. On the other hand, the Court struck down lending equipment and providing auxiliary services because they created

\footnotetext{
${ }^{3}$ Mitchell v Helms(2000) overruled this decision

Year 5/ 2021, Volume-5, Issue-1 | WwW.ispecjournal.org
} 
impermissible effect of advancing religion as well as excessive entanglement with the state (Crisafulli, 2003, p.2238)

In Wolman $v$ Walter (1977), the Court evaluated the constitutionality of Ohio statute that provided textbook lending, state funded standardized tests, some health services, materials and equipment. The Court found the first three programs permissible while it stuck down the program providing materials and equipment to private schools. Relying on the Meek's rationale, the Court ruled that the last program had direct impact to advance religion because this equipment might be used in religious instruction as well. The Court highlighted the difficulty of separating the secular education from the sectarian. Similarly, in Aguilar v. Felton $(1985)^{4}$, the Court found the New York program providing remedial assistance in sectarian schools impermissible (Crisafulli, 2003, p. 2238-40). In a companion case, School District of Grand Rapids v Ball, the Court struck down a program that hired private schools, mostly religious, to teach after school courses (Greenawalt, 2008, p. 406).

In contrast to 1970 s cases, the cases 1980 s marked a turn towards a more permissive approach. In the case of Mueller $v$ Allen(1983), the Court evaluated the constitutionality of the Minnesota statute that allowed parents to deduct educational expenses for tuition, textbooks and transportation from their state income tax payments. The Court upheld the Minnesota statute on the grounds that the deduction was available to all parents and that the aid to parochial schools would reach indirectly through the personal choices of parents (Greenawalt, 2006, p. 405).

In Witters $v$ Washington Department Services for the Blind (1986), a unanimous court ruled that a claimant, who studies at a private Christian college, may use state funds under a program for vocational rehabilitation of the blind on the grounds that only a small amount of money transfers to the religious institution and that the funding program was available to everyone. Furthermore, the Court highlighted that the aid to religious instruction was "only as a result of the genuinely independent and private choice of aid recipients" (Witters $v$ Washington Department Services for the Blind, p. 487). In Zobrest $b$ Catalina Foothills School District (1993), the Court reached a similar conclusion about a public funding for a sign language interpreter at a parochial high school (Greenawalt, 2008, p. 408).

In 1997, the Court reexamined the Aguilar case in Agostini v Felton and overruled the previous decision. Justice O'Connor wrote for the Court that the New York statute "does not

\footnotetext{
${ }^{4}$ This New York program later was upheld in Agostini v. Felton, 521 U.S. 203 (1997)
}

Year 5/ 2021, Volume-5, Issue-1 | WWW.ispecjournal.org 
result in governmental indoctrination; define its recipients by reference to religion; or create an excessive entanglement (Agostini v Felton, p.234). Following the rationale of the Agostini case, in Mitchell $v$ Helms (2000), the Court found that the Chapter 2 of Education Consolidation and Improvement Act of 1981, which provides educational equipment and computers to both public and private schools, was compatible with the Constitution (Crisafulli, 2003, p. 2248). The Court said that since 'secular purpose' of the Chapter 2 is agreed upon, the examination should be on the 'effect' of the Chapter 2. Quoting Agostini, the Court examined whether the program "results in governmental indoctrination" or "defines its recipients by reference to religion" (Mitchell v Helms, p. 794). The Court ruled that the program was neutral and did not aim to advance religion.

In sum, the Court has struck down paying the salaries of teachers employed at parochial schools to teach secular subjects with public funds as well as tuition reimbursements and maintenance grants available only to private school students. On the other hand, the Court has approved programs providing bus transportation and secular textbooks to parochial school students and a program providing computers and books to parochial schools. The Court held that these programs provided "secular, neutral, or nonideological services, facilities, or materials" (Lemon v Kurtzman, p.616) and these programs were provided to all students "regardless of the type of school they attended" (Board of Education v Allen, p. 241). Therefore, when the state was neutral with a secular purpose, the Court did not find any danger of governmental endorsement of religion (Crisafulli, 2003, p. 2231). The case of Mitchell $v$ Helms expanded the scope of permissible aid and paved the way for the decision that came with the Zelman case. Overall, the case law on parochiaid presents a transformation from a separationist stance to an accommodationist one. Even though in Locke $v$ Davey 2004, the Court found no violation of free exercise of religion in exclusion of clerical training from general government aid, the ruling does not contradict with the recent permissive approach of the Court because the Locke decision is limited to clerical training which is 'essentially religious endeavor'. 5

In short, there are two main concepts, "incidental benefit" (via choice) and "secular nature" of the government program, which became established parameters of the Court's Establishment Clause jurisprudence on parochiaid cases (Underkuffler, 2000, p. 176). In the light of the

\footnotetext{
5 See, Trinity Lutheran Church of Colombia v Carol S. Comer, Director, Missouri Department of Natural Resources ( 2017 ), p.12
}

Year 5/ 2021, Volume-5, Issue-1 | www.ispecjournal.org 
recent Court cases, the criteria set by the Court for the government financial aid to religious schools can be listed as follows:

1) The aid program has to be neutral and generally accessible.

2) "True private choice" and "neutrality" are the main principles that govern the Establishment Clause jurisprudence on financial aids to religious schools.

3) Unspecified aid in the form of scholarship or voucher can reach the religious institutions only through private choice while religious schools can participate aid programs in the form of specific secular benefit such as textbooks, computers or construction materials.

4) The establishment standards for aid programs involving primary and secondary schools are stricter than the ones for tertiary education. For first levels of education, the test of 'the primary effect of advancing religion' is stricter. Permissible aid to primary and secondary religious schools have always involved a clear secular aspect, that is to say, the aid was made to support secular aspect of the education offered by such schools. However, it is possible for a government program to sponsor devotional religious education in religious colleges and universities as college students have genuine independent choice in determining their majors. The student choices need not to be religious (Bovee and et al,1987, p.400-402). However, states might have stricter disestablishment rules. In this context, their general aid programs might reject sponsoring devotional religious education. However, states cannot eliminate any institution from general aid programs merely because they are religious. For example, general aid programs may not reject sponsoring a business program taught in a religious college, which constitutes discrimination against religious identity.

\section{Analysis of Zelman v Simmons-Harris}

First of all, the First Amendment approval of a government program does not necessarily mean that the program is fair and beneficial to the American public in terms of other aspects of social justice and equality. The voucher scheme has been a highly contentious issue. Advocates and opponents raise contesting arguments on the benefits and harms of vouchers (Green, 2003, p.554-8). Assessment of these arguments is beyond the scope of this project. This chapter focuses on assessment of arguments related to the Supreme Court's 
jurisprudence on religion. When it comes to legal objections to the voucher scheme, they can be briefly summarized as follows: 1) It offers unprecedent substantial aid to parochial schools without restricting it to secular use. 2) overwhelming majority of the participating institutions is religious. 3) the program does not offer genuine free choice 4) It creates the high risk of divisiveness along the religious lines (Greenawalt, 2008, p. 417)

The Zelman case was decided on the basis of two criteria: state neutrality and private choice, which were established in Everson v Board of Education (1947). Even though the majority opinion did not explicitly refer to the Lemon case, it briefly addressed the principles set by Lemon, yet merged 'excessive entanglement' into the inquiry of 'effect' (Justice O'Connor, Concurring Opinion). The Court followed the rationale of Mitchell v Helms (2000) and analogized the voucher program to the permissible programs previously upheld by the Mueller, Witters, and Zobrest decisions summarized above.

\subsection{Does Zelman Mark a Radical Break from the Past?}

The historical review of the parochiaid cases is necessary to understand and situate the Zelman case in the Court's trajectory. Given this background (summarized above), the Zelman case does not represent a 'radical break' but marks another stage in the accommodationist evolution of the Court's stance on the parochiaid issue. The change in Court's attitude towards parochial schools appears to be more pronounced in the Zelman case because the Court for the first time approved basic tuition coverage without any restriction, which enables the aid to indirectly pay teachers' salaries and other expenses tied to sectarian preferences and dealings. The benefit via voucher is not identifiably secular like a text book and hence it is not possible to keep the actual usage of the voucher under the control of a public entity. Thus, the actual usage of voucher is not restricted to secular uses only. Furthermore, the benefit via voucher is not supplemental, it is designed to cover the basic tuition expense. In short, the voucher scheme is qualitatively different from any form of aid previously approved by the Court. Therefore, this unrestricted and divertible nature of voucher makes the Zelman case stand out in the history of parochiaid cases of the Court.

In evaluating the constitutionality of state aid to parochial schools, the Court has applied the Lemon and the endorsement tests, even though the interpretational engagements have not always been consistent (Underkuffler, 2000, p. 171-3). In the Agostini case, the Court clearly stated that its doctrinal tests have not changed and the Court "continues to ask whether the

Year 5/ 2021, Volume-5, Issue-1 | WWW.ispecjournal.org 
government acted with the purpose of advancing or inhibiting religion" and "whether the aid has the 'effect' of advancing or inhibiting asking, for example, "whether the state program creates an impermissible 'symbolic link' between government and religion" (Agostini v Felton, p.224).

Greenawalt states that the Everson opinion can be used to support a variety views about school aid. The language used in the opinion highlighted that the benefits were given to parents not to schools and the opinion emphasized that individuals cannot be excluded from receiving public welfare benefits because of their faith or lack thereof. Yet, the opinion also emphasized the marginal contribution of the state aid to the parochial school (Greenawalt, 2005, p.395). In short, some passages in the Everson opinion can be used to consolidate the majority opinion in the case of Zelman v Simmons-Harris, while some others can be used to support the dissenting judges' position.

Proponents of the voucher program argue that the vouchers in the Zelman case is no different than the bus transportation in the Everson which was upheld by the Court (Underkuffler, 2000, p. 168). According to this argument, neutral state programs have been approved by the Court. The following quote from the Everson can be read to support the advocates and the majority position in Zelman: "That Amendment requires the state to be a neutral in its relations with groups of religious believers and nonbelievers; it does not require the state to be their adversary. State power is no more to be used so as to handicap religions than it is to favor them" (Everson, p.18).

On the contrary, Justice Souter's dissenting opinion states that the previous cases always measured the scale of the aid both in the number of dollars and in the proportion of systemic school expenditure supported. The dissenting judges contend that the majority opinion renders substantiality irrelevant, which is unprecedented. Furthermore, the aid in the Zelman case could be divertible to non-secular expenses, which is also unprecedented. Similarly, in the Everson case, the Court points to the marginal and limited contribution of the state aid to the parochial schools (Everson, p. 18).

Segal and Spaeth argue that Supreme Court justices decide along the lines of their policy preferences. Justices function as policy makers in their analysis of the Supreme Court. "Simply put, Rehnquist votes the way he does because he is extremely conservative; and Marshall voted the way he did because he was extremely liberal" (Segal and Spaeth, 2002, p. 86). Similarly, Hansford and Spriggs state that the exact role of law in Supreme Court 
decision-making is still unclear. They explain that because of the complexity of law and the difficulty in quantifying the concept of precedent, the judicial literature still lacks fully developed theoretical and empirical understanding to clarify why and when law changes (Hansford and Spriggs, 2006). In this context, some scholars rely on the ideology of judges more than the content of court opinions and the precedents (Fowler and Sangick, 2008, p.18). On the other hand, Epstein and Knight rejects Segal and Sapaeth's analysis of the Supreme Court. Instead, they offer their 'strategic account' which argues that justices act rationally to maximize their policy preferences, yet they act within the constraints of their legal institutions and hence try 'strategically' to convince their collogues with their reasoning. So, justices strategically operate within the institutional restrains (Epstein and Knights, 1998, p. xiii).

The Zelman decision by the divided Court is a perfect place to think about these analyses mentioned above. A close reading of the majority and dissenting opinions reveals that the differences between justices might be genuine implementation of the precedents with different analyses and varying contextual interpretations of the case in hand. As illustrated with the Everson example above, it is possible to interpret the precedents in opposing ways in new cases before the Court. Although the analyses mentioned in the previous paragraph suggest some plausible explanations, it is not possible to exactly pinpoint why a justice reads a precedent in his/her particular way. However, it is possible to argue that the uncompromising differences of justices in reading and implementing precedents do not necessarily mark this case as 'a radical break' from the past.

\subsection{Does the Amount of Indirect Aid to Religious Institutions Matter in Evaluating Constitutionality of Government Financial Support Programs? Should the Court follow a formalist approach based on strict constitutional criteria or a realist approach based on contextual differences?}

In the Court's history, there are three main stances on the amount of aid to the parochial schools. First, the dissenting justices in Zelman and the quote from the Everson opinion mentioned above emphasize the marginal amount of government aid to the religious schools. Furthermore, Justice O'Connor's concurring opinion also highlights the small portion of the aid compared to the state's overall education expenditure. Second, separationist justices highlighted the risk of allowing even a small amount of aid to parochial schools. In Allen, Justice Black argued that "tax-raised funds cannot constitutionally be used to support religious

Year 5/ 2021, Volume-5, Issue-1 | WWW.ispecjournal.org 
schools, buy their school books, erect their buildings, pay their teachers, or pay any other of their maintenance expenses, even to the extent of one penny" (J. Black's dissenting opinion in Board of Educ. v Allen). Also, the theory of indirect aid has been heavily criticized by those who argue that "taxpayers should not be compelled to pay even 'three pence' in support of religious institutions that those taxpayers oppose" (J. Rutledge dissenting in Everson v. Board of Educ.). Third, the majority in Zelman highlights that the amount of indirect aid is irrelevant. It states as follows: "Five Members of the Court, in separate opinions, emphasized the general rule from Mueller that the amount of government aid channeled to religious institutions by individual aid recipients was not relevant to the constitutional inquiry. Our holding thus rested not on whether few or many recipients chose to expend government aid at a religious school but, rather, on whether recipients generally were empowered to direct the aid to schools or institutions of their own choosing" (Zelman, p. 651).

Even though the majority opinion in Zelman did not find the amount of aid relevant to the case, the majority of the justices in the Zelman case as well as in the previous parochiaid cases consider substantiality a relevant discussion in evaluating establishment cases. Justice O'Connor confronts that the aid via the voucher program is indeed insignificant amount compared to the total educational expenditure of Ohio State. Even though Justice O'Connor disagrees with the dissenting justices on the case in hand, she still highlights the small portion of aid that would reach to the religious institutions. In other words, they all agree on the importance of substantiality of the aid. Overall, as Greenawalt states, following a contextual and realistic approach rather than a formalist one in interpreting the constitutionality of government aid to religiously-affiliated schools has been more common in the history of the Court (Greenawalt, 2008, p. 419-420). The reasoning in the majority opinion diverges from this traditional reasoning of the Court's previous majority opinions.

\subsection{Is the Voucher Program Really Neutral?}

Similar to the plurality opinion in Mitchel v Helms (2000), the Zelman majority opinion relied on the principle of neutrality. However, although the voucher program is formally neutral, further examination of the context casts doubt on its neutrality. As Justice Souter contends that the amount set for vouchers discourage secular private schools from attending the program. In Cleveland, the average tuition charged by the Catholic schools was 1,592\$ while an average tuition charged by private secular schools was 3,500\$ during the 1999-2000

Year 5/ 2021, Volume-5, Issue-1 | WWW.ispecjournal.org 
academic year. The voucher program does not allow the participating schools to charge more than $250 \$$ as co-payment (J. Souter, p. 704-5).

To answer the question of neutrality, the majority opinion emphasizes that the issue should be evaluated from the viewpoints of the parents and asks "whether Ohio is coercing parents into sending their children to religious schools"(Zelman, p. 655). In this context, the majority opinion points to the public school alternatives such as magnet schools and community schools. However, Justice Souter contends that the comparison should be among the schools that can use vouchers. Thus, public and non-public comparison is a false one. When the nonpublic options are compared, Justice Souter's argument seems to be accurate. Yet, when the all options are considered, the parents seem to have a wide range of choices not to send their children to parochial schools. In this context, the program seems to pass neutrality test based on religion. However, there should be a thorough examination whether or the public school options are viable alternatives to private parochial schools. This is a crucial issue whether this voucher program is fair to the American people. However, this is an issue of 'public v private', rather than 'religious v secular'.

Some scholars argue that the majority opinion displays a high degree of formalism neglecting the real effect of the program (Green, 2003, p.572) Justice Souter states that while the voucher program may not facially discriminate among religious groups, it will likely lead to substantive inequality among religions benefiting those faiths with established private schools such as those of Catholics, Lutherans, and Orthodox Jews (J. Souter, dissenting opinion). Scholars and justices embrace varying stances on neutrality. As can be seen in their dissenting opinions, Justices Scalia and Thomas argue for formal neutrality in their evaluations of Establishment and Free Exercise Clauses. Scalia and Thomas's position would mostly benefit majority religions. On the other hand, Douglas Laycock, suggests that substantive neutrality is a better concept than formal neutrality (Laycock, 1990, p. 999-1002). Thomas Berg, Michael McConnel, Stephen Monsma and H. Breyer agree that religious practices require special accommodation under the Free Exercise Clause and careful evaluation under the Establishment Clause, which requires government to refrain from both advancement of religion and putting substantial burden on religious practices and choices. (Berg and Laycock 2004, Breyer 1994, Monsma 2000). On the other hand, not only conservatives like Scalia and Thomas but also separationists utilize the concept of formal neutrality in support of their respective positions (Breyer, 1994, p. 472).In short, the Court has followed the principle of 
'neutrality' in the recent decisions involving religion and determined what is hostile to religion in conjunction with this principle (Ravitch, 2004, p. 1032).

\subsection{Divisiveness:}

Lastly. I would like to touch on the issue of divisiveness. At first glance, the Justice Breyer's argument about divisiveness sounds subsidiary in the examination of constitutionality. Yet, a more careful consideration can see his point about the root cause in the historical development of the disestablishment. Religious conflict and divisiveness were the historical reason to guarantee disestablishment in the Constitution. Therefore, the divisiveness argument is a challenging question for the reasoning of the majority.

According to Greenawalt, neutrality in distributing the vouchers does not necessarily wipe out the undesirability of using state aid in sectarian schools. Legislative decisions over educational funding can cause fights over the state budget, as minorities and seculars could not equally benefit from such decisions. Furthermore, even if the voucher program operates on the basis of individual choice, the program might be detrimental to the development of good citizenship and diversity. An extensive flow of government money into sectarian schools could divide the population along the lines of religious affiliation (Greenawalt, 2005, p. 389). Although opponents lost the argument on the constitutionality, they will continue their battle through politics (Crocker, 2005, p.423).

\section{Conclusions}

The Zelman case clearly establishes that it is possible for the government to support religious instruction indirectly, i.e., the government financial aid can reach to parochial schools via private choices of individuals eligible to participate in the neutral government programs. The vouchers in the Zelman case are used to pay tuitions that covers all type of educational services of the parochial schools, including religious ones. Thus, government indirectly sponsors religious instruction in these schools.

It offers unprecedent substantial aid to parochial schools without restricting it to secular use. Given the historical review of the parochiaid cases, the Zelman case does not represent a 'radical break' but marks another stage in the accommodationist evolution of the Court's stance on the parochiaid cases. The change in Court's attitude towards parochial schools appears to be more pronounced in the Zelman case because the Court for the first time 
approved basic tuition coverage without any restriction, which enables the aid to indirectly pay teachers' salaries and other expenses tied to sectarian preferences and dealings.

Unlike the direct government aid to religious activities in various European and Turkish political systems, the American government supports religious instruction only indirectly. Even though the government programs providing financial aid for religion has always faced rigorous examination in the Supreme Court, the current case law of the Court opens the door for a significant amount of unspecified cash flow to religious schools. Thanks to this constitutional pass, it is possible for future politics and legislative endeavors to reshape the contours of state-religion relations in the field of education. Thus, the distinct feature of American secularism based on separation between church and state might bend further.

\section{References}

- Bell, Ashley M. (2001). God Save this Honorable Court: How Current Establishment Jurisprudence can be Reconciled with the Secularization of the Historical Religious Expression”. American University Law Review 50(1), 1273-1320.

- Berg, Thomas and Laycock, Douglas. (2004). The Mistakes in Locke v Davey and Future of State Payments for Services Provided by Religious Institutions. Tulsa Law Review 40 (1), 226-254.

- Breyer, Hugh J. (1994). Laycock's Substantive Neutrality and Nuechterlein's Free Exercise Test: Implications of Their Convergence for the Religion Clauses. Journal of Law and Religion 10(1), 467-490.

- Bovee and et al. (1987) Case Comment: Witters v. Washington Department of Services for the Blind: The Establishment Clause and Financial Aid to Students for Religious Education at Private Institution. Journal of College and University Law, 13(4), 397-406

- Crisafulli, Sara J. (2003). Zelman v Simmon-Harris: Is the Supreme Court's Latest Word on School Voucher Programs Rally the Last Words?. Fordham Law Review,71, 2227-2281.

- Crooker, Virginia Chase. (2005). “Zelman v. Simmons-Harris: The Establishment Clause and the Fight for School Vouchers". Arkansas Law Review, 58, 395- 424

- Dreisbach, Daniel. (2002). Thomas Jefferson and the Wall of Separation Between Church and State. New York: New York University Press.

Year 5/ 2021, Volume-5, Issue-1 | WwW.ispecjournal.org 
- Epstein, Lee and Knight, Jack. (1998). The Choices Justices Make, C. Quarterly,

- Fowler, James H. and Jeon, Sangick. (2008). The Authority of the Supreme Court Precedent. Social Networks, 3(1), 16-30.

- Greenewalt, Kent. (2005). History as Ideology: Philipp Hamburger's Separation of Church and State. California Law Review, 93(1), 367-396.

- Green, Steven K. (2003). The Illusionary Aspect of Private Choice for Constitutional Analysis. Willamette Law Review, 38(1), 548-578.

- Greenawalt, Kent. (2008). Religion and the Constitution. New Jersey: Princeton University Press

- Griffin, Leslie C. (2010). Law and Religion. New York: Aspen Publishers.

- Hamburger, Philipp (2002). Separation of Church and State. Massachusetts: Harvard University Press.

- Hansford, Thomas, and Spriggs, James. (2006). The Politics of Precedent on the US. Supreme Court. New Jersey: Princeton U. Press.

- Kritzer, Herbert M. and Richards, Mark J. (2003). Jurisprudential Regimes and Supreme Court Decision Making: The Lemon Regime and the Establishment Clause Cases. Law and Society Review 37(4), 827-840.

- Laycock, Douglas (1990). Formal, Substantive, and Disaggregated Neutrality Toward Religion. DePaul Law Review, 30(1), 993-1018.

- Marietta, Morgan. (2014). A Citizen's Guide to Constitution and the Supreme Court. New York: Routledge.

- Monsma, Stephen V (2000). Substantive Neutrality as a Basis for Free Exercise-No Establishment Common Ground. Journal of Church and State, 42(1), 13-35.

- Munoz, Vincent Philip. (2003). James Madison's Principle of Religious Liberty. American Political Science Review, 97(1), 17-32

- Segal, A Jeffrey and Spaeth, Harold J. (2002). The Supreme Court and the Attitudinal Model Revisited. Cambridge: Cambridge University Press.

- Peterson and et al. "An Evaluation of Cleveland Voucher Program after Two Years". Program on Education Policy and Governance. Accessed via https://eric.ed.gov/?id=ED451260. 


\section{ISSN 2717-7262 ISPEC Journal of Social Sciences \& Humanities}

- Ravitch, Frank S. (2004). A Funny Thing Happened on the Way to Neutrality: Broad Principles, Formalism, and the Establishment Clause. Georgia Law Review, 38(2), 489-573.

- Ravitch, Frank S. (2004). The Supreme Court's Rhetorical Hostility: What is Hostile to Religion Under the Establishment Clause?. BYU Law Review 2004, 3, 1030-1047.

- Underkuffler, Laura (2000). Vouchers and Beyond: The Individual as Causative Agent in the Establishment Jurisprudence. Indiana Law Journal 75(1), 167-190.

Cases:

- Everson v Board of Education, 330 U.S. 1 (1947)

- Board of Education v Allen, 392 U.S. 236 (1968)

- Lemon v. Kurtzman, 403 U.S. 602 (1971).

- Meek v Pittenger, 421 U.S. 249 (1975)

- Wolman v Walter, 433 U.S. 229 (1977)

- $\quad$ Muller v Allen, 483 U.S. 388 (1983)

- Wallace v. Jaffree, 472 U.S. 38 (1985).

- Aguilar v. Felton, 473 U.S. 402 (1985)

- School District of Grand Rapids v Ball, 473 U.S. 373 (1985).

- Witters v Washington Department Services for the Blind, 474 U.S. 481, (1986)

- Zobrest b Catalina Foothills School District, 509 U.S. 1 (1993)

- Agostini v. Felton of 1997, 521 U.S. 203 (1997).

- Mitchell v Helms, 530 U.S. 793 (2000).

$\begin{array}{llllll}\text { - Zelman } & \text { v. } & \text { Simmons-Harris, } & 536 & \text { U.S. } & 639\end{array}$ Locke v Davey, 540 U.S. 712 (2004)

- Trinity Lutheran Church of Colombia v Carol S. Comer, Director, Missouri Department of Natural Resources, 582 U.S. (2017)

- 72 F.Supp.2d 834 (1999)

- Sixth Circuit, Simmons-Harris v Zelman, No: 00-3055/3060/3063. 